\title{
Blood and Wine
}

\section{Shaun McCann ${ }^{1}$}

Received: 21 January 2019 / Accepted: 21 January 2019 / Published online: 4 February 2019

C Springer Nature Limited 2019

Go, eat your food with gladness and drink your wine with a joyful heart, for God has already approved what you do.

\section{Ecclesiastes 9:7 NIV.}

When you are sipping a glass of wine you rarely think about blood. Blood and wine, however, have been associated with each other since time immemorial. Based on the New Testament account of the Last Supper in the New King James version of the Bible [1], Roman Catholics and some other Christian sects believe that wine is converted into the blood of Christ during the Eucharist: 'After the same manner also He took the cup, when He supped saying, this cup is the new Testament in my blood; this do ye, as oft as ye drink, in remembrance of me'. Many people including a German priest, Peter of Prague, in 1263 had some difficulty in believing in transubstantiation until blood apparently seeped from the consecrated host and flowed onto the corporal (a white linen cloth on which the consecrated host is placed during mass). Serratia marscences is a bacterium (originally thought to be a fungus) which produces a red pigment, prodigiosin, which can colonize damp statues, polenta and communion wafers. It is now believed to be responsible for some 'bleeding' statues and may explain Pater of Prague's experience. The doctrine of transubstantiation was, however, hotly disputed in the 16th century and led, since then, to many disagreements and even wars.

Although many of you have queued to see Leonardo's Last Supper (L'Ultima Cena) in Milan, there is a beautiful Last Supper fresco in the Vallambrosan monastery at Badia a Passignano near the town of Panzano

Shaun McCann

shaunrmccann@gmail.com

1 Department of Haematology and Academic Medicine, St James' Hospital and Trinity College, Dublin, Ireland in Tuscany. The fresco was created by Ghirlandaio, Michelangelo's teacher, in the 15 th century and although it may not have the same psychological import as Leonardo's Last Supper there are no queues! (Fig. 1)

The connection between wine and religion is not confined to the conversion of wine into blood but the use of Vin Santo (holy wine) during the Catholic mass. Vin Santo, a sweet wine, made from dried Malvasia or Trebbiano grapes and kept in wooden barrels (caratelli) for 6 years or more is common in Tuscany, however, its origin may be from the Aegean island of Santorini when the Venetians were in charge. In Tuscany most people like to drink Vin Santo at room temperature with almond biscotti known as 'cantucci' which they dunk into the wine. My preference is to drink Vin Santo well chilled with some Pecorino nero semi stagginata (cheese made from ewe's milk). Two noted makers of Vin Santo are Isole e Olena in Barberino Val d'Elsa and San Giusto a Rentannano in Gaiole but there are many others. Whatever the origin of this wine many people believe that it helped to keep some vineyards open in California during the disastrous years of

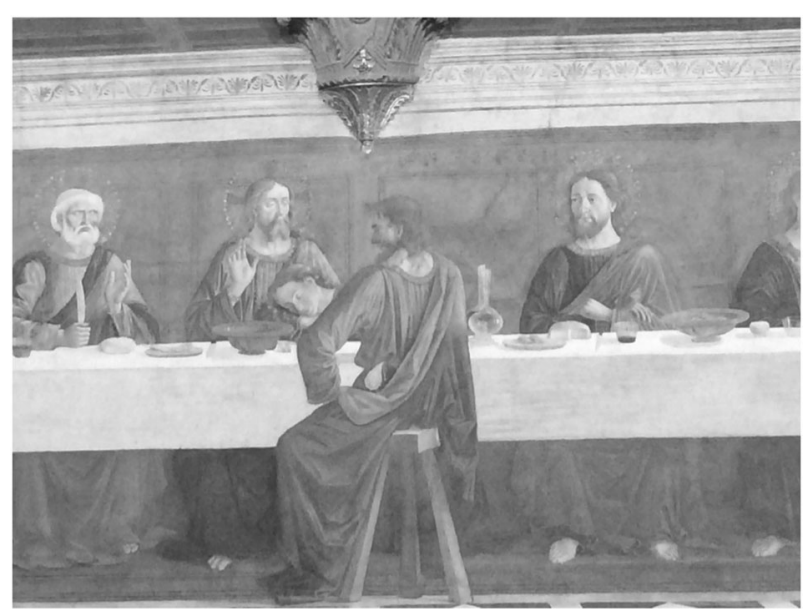

Fig. 1 Photograph of detail of the Last Supper (L'Ultima Cena) fresco in Badia a Passignano, Tuscany, Italy 


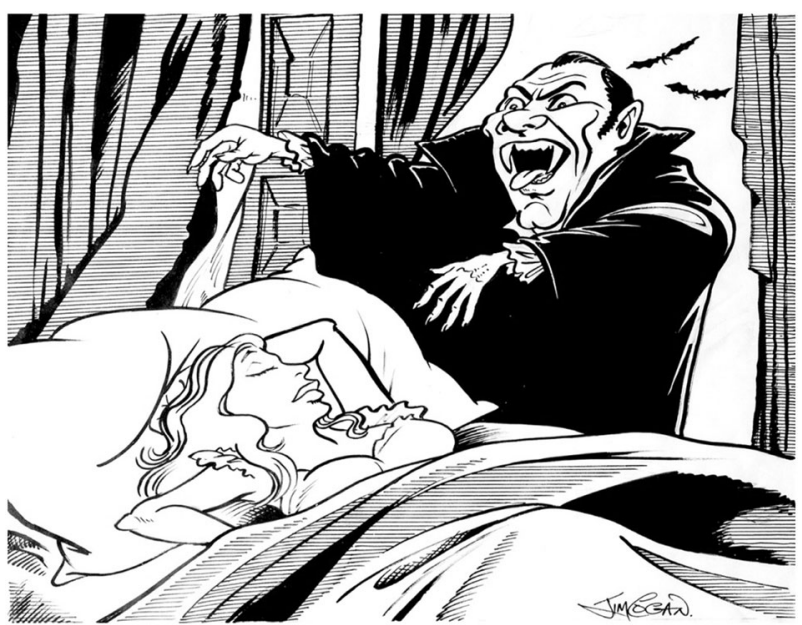

Fig. 2 Dracula. With permission of the artist James Cogan

prohibition as wine produced for religious ceremonies was not prohibited!

Although we, as transplanters, know about the existence of stem cells, ancient history tells us that people believed that blood contains something special, like memory, bravery and other emotions. Herodotus, the father of Western history, tells us that the Scythians, who occupied what we now call Iran, drank the blood of their slain enemies who fought well, presumably believing that the quality of bravery was contained in their blood [2]. While physicians in the 17th century in England and France explored the possibility of blood transfusion they nevertheless held on to the belief that blood contained some extraordinary qualities. Questions such as: 'if blood was transfused from a dog which would catch a bone to a dog without this ability would the ability be transfused with the blood'? were asked. Of course the ultimate 'blood experience' is the vampire myth, made world famous by Dubliner Bram Stoker in his novel 'Dracula' [3] (Fig. 2). In the book Professor van Helsing understood that severe anemia from blood-sucking could lead to heart failure and that this could be corrected by blood transfusion even though blood groups had not yet been discovered.
However, we now know that blood contains pathogens which until recently were unknown. The HIV viral infection, which resulted in many deaths, and the "mad cow' debacle, which happily did not result in the number of deaths predicted, are two modern examples of unsuspected pathogens transmitted by blood. In the case of HIV infection, the medical profession did not cover itself in glory however with the advent of nucleic acid testing the transmission of HIV via blood transfusion has become rare.

In recent times a number of other pathogens have been described which can be transmitted through blood transfusion such as West Nile Virus and Zika Virus (transmission by platelet transfusion confirmed). Presumably, Ebola could be transmitted through blood transfusion but infected individuals are too ill to become blood donors.

The idea that blood contains special qualities such as memory may seem quaint to us now but the idea of transmission of pathogens via transfusion is relatively recent. Whatever the beliefs, blood transfusion can be lifesaving and efforts to make it safer continue.

In the meantime I'll continue to drink wine as it is good for the blood!

\section{Compliance with ethical standards}

Conflict of interest The author declare that he has no conflict of interest.

Publisher's note: Springer Nature remains neutral with regard to jurisdictional claims in published maps and institutional affiliations.

\section{References}

1. The New King James Version. Thomas Nelson. Nashville. TN. 1982.

2. McCann Shaun R. A History of Haematology: from Herodotus to HIV. 2016. Oxford Medical Series. Series advisor Christopher Gardner - Thorpe. Oxford University Press, UK. ISBN: 978-0-19871760-7.

3. Stoker B Dracula. 2011. Oxford University Press. UK. 